\title{
Examining school-level implementation of British Columbia, Canada's school food and beverage sales policy: a realist evaluation
}

\author{
Adrienne V Levay ${ }^{1}$, Gwen E Chapman ${ }^{2, *}$, Barb Seed ${ }^{3}$ and Hannah Wittman 4 \\ ${ }^{1}$ Integrated Studies in Land and Food Systems, Faculty of Land and Food Systems, University of British Columbia, \\ Vancouver, Canada: ${ }^{2}$ College of Social and Applied Human Sciences, University of Guelph, Guelph, Canada: \\ ${ }^{3}$ Independent Consultant in Food and Nutrition Policy, Vancouver, Canada: ${ }^{4}$ Center for Sustainable Food Systems, \\ University of British Columbia, Vancouver, Canada
}

Submitted 5 January 2019: Final revision received 2 July 2019: Accepted 16 September 2019: First published online 11 March 2020

\begin{abstract}
Objective: To identify key school-level contexts and mechanisms associated with implementing a provincial school food and beverage policy.

Design: Realist evaluation. Data collection included semi-structured interviews ( $n$ 23), structured questionnaires ( $n$ 62), participant observation at public events ( $n$ 3) and scans of school, school district and health authority websites ( $n$ 67). The realist heuristic, context + mechanism $\rightarrow$ outcome configuration was used to conduct the analysis.

Setting: Public schools in five British Columbia (BC), Canada school districts. Participants: Provincial and regional health and education staff, private food vendors and school-level stakeholders.

Results: We identified four mechanisms influencing the implementation of BC's school food and beverage sales policy. First, the mandatory nature of the policy triggered some actors' implementation efforts, influenced by their normative acceptance of the educational governance system. Second, some expected implementers had an opposite response to the mandate where they ignored or 'skirted' the policy, influenced by values and beliefs about the role of government and school food. A third mechanism related to economics demonstrated ways vendors' responses to school demand for compliance with nutritional Guidelines were mediated by beliefs about food preferences of children, health and food. The last mechanism demonstrated how resource constraints and lack of capacity led otherwise motivated stakeholders to not implement the mandatory policy.

Conclusion: Implementation of the food and beverage sales policy at the school level is shaped by interactions between administrators, staff, parent volunteers and vendors with contextual factors such as varied motivations, responsibilities and capacities.
\end{abstract}

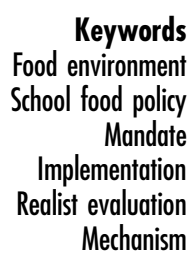

Global concern about increased prevalence of obesity and overweight in children ${ }^{(1)}$ and the predicted healthcare costs and loss of economic productivity once they become adults $^{(2,3)}$ are key drivers of school food environments emerging as popular targets for public health interventions. School food environments are the physical, economic, political and socio-cultural context in which consumers engage with the food system to make their decisions about acquiring, preparing and consuming food ${ }^{\text {, }(4, \text { p. } 28)}$ during the school day. Nutrition standards for foods and beverages provided and/or sold in schools have been introduced in many jurisdictions, including Mexico, Australia, the Netherlands, Finland, Norway, some regions of France and most American and Canadian jurisdictions ${ }^{(5-13)}$. These types of standards aim to increase availability of healthy options and reduce and eliminate less healthy ones.

Evaluations from various international jurisdictions have found different levels of compliance across different contexts such as rural $v$. urban settings ${ }^{(14-17)}$, school type ${ }^{(14,15,18-20)}$, school size $\mathrm{s}^{(15,19)}$ and school sociodemographics ${ }^{(13,17,21,22)}$. These studies have also found non-compliant food to be widely available even after 
implementation efforts are made ${ }^{(15,20,23-27)}$, with fluctuating levels of compliance from year to year ${ }^{(18)}$. These primarily quantitative evaluations provide important insight as to whether the introduction of food and beverage sales policies results in increased availability of healthy options and decreased availability of unhealthy ones (does $x$ lead to $y$ ? $)^{(28)}$. However, they do not provide insight about why these various levels of compliance occur (what is it about $x$ that leads to $y$ ?).

Qualitative research has identified several barriers and facilitators to the implementation of school food sales policies. These include a lack of understanding about what the policy is ${ }^{(29-32)}$, concerns about profit margins ${ }^{(10,14,32-34)}$, the paternalistic nature of school food and beverage sales policies ${ }^{(30-32,34-36)}$ and a generic lack of

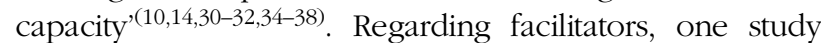
from Australia identified that top-down pressure helps to support implementation efforts $^{(16)}$ along with having someone in the school with a high level of interest to implement ${ }^{(31,39)}$. These qualitative studies tend to identify barriers and facilitators to implementation as discrete components of the complex social processes associated with implementation (i.e. in catalogued lists). Missing from this body of work is the exploration of the relationships between implementation barriers and facilitators that lead expected implementers to decide to engage in implementation activities and the role of context in shaping these relationships.

This gap in knowledge may be related to the methodological challenges of examining the complexity of human behaviour associated with implementing social interventions ${ }^{(40,41)}$. Complex public health interventions often have multiple, linked components rolled out for individuals or communities, involving national, regional and/or local levels of implementation activities. Further, intervention success is dependent on how individuals and institutions respond to the intervention and the broader social, economic, cultural and political contexts in which they are launched. What may work in some contexts, for some people, may not work in another, so there is a need to deeply understand the nature of complex initiatives $^{(42,43)}$.

One aspect of the complexity of school food and beverages sales standards is that they are implemented at different levels and across sectors - provinces or states, districts, schools and the private sector each have different roles. For a nuanced understanding of implementation processes, it is helpful to examine and assess distinct experiences across these levels where different types of stakeholders and activities exist and occur. The analyses presented in this paper are part of a larger study of the implementation of British Columbia (BC), Canada's school food and beverage sales policy at the district and school levels. Here, we focus on the school-level experience; the experience of school districts is reported elsewhere ${ }^{(44,45)}$. In particular, we explore the way in which key mechanisms and contexts influence how school-level stakeholders engage in implementation activities.
British Columbia's Guidelines for Food and Beverage Sales in BC Schools ('the Guidelines') were first created in 2005 by the provincial government, with the most recent iteration launched in January 2014. These Guidelines apply to all public schools and consist of nutrient-based criteria per portion or serving, focusing on reducing the amount of salt, sugar and fat in items sold to students in all school venues. These may include vending machines, cafeterias, fundraisers, sports days and school stores. The Guidelines are mandatory 'on-paper' but, to-date, no enforcement measures have been implemented. In addition, the British Columbia Ministry of Education allows the province's sixty districts to determine how they will carry out these directives and, in turn, school districts allow their individual schools a high level of autonomy to make decisions about school-level implementation.

The purpose of the current study is to identify key contexts and mechanisms associated with implementing complex school food and beverage sales interventions, using BC's provincial school food and beverage sales policy as a case study. It provides an increased depth of understanding for practitioners and decision-makers about the complex social processes associated with implementing school food and beverage sales policies. In addition, we identify leverage points at which implementation challenges may be addressed and expected outcomes of this type of policy might be achieved.

\section{Methods}

\section{Overall methodological approach: realist evaluation of implementation}

Because BC's school food and beverage sales policy has the hallmarks of a complex intervention, we adopted a realist evaluation approach. A key feature of this approach is the use of the 'context + mechanism $\rightarrow$ outcome' (CMO) hermeneutic as a framework (summarised in Table 1). Explanations for why implementation and uptake of a given intervention happens and the way it does are inferred through identification of relationships between contexts, mechanisms and outcomes. Contexts, defined as the 'backdrop' for an intervention ${ }^{(46, \text { p. 3) }}$, are components of a social system that can include social or cultural norms, histories of organisations or people and/or structures of governance. Mechanisms are defined as the interaction between intervention resources (tangible or non-tangible) and stakeholders' response to them (resource + reasoning). Stakeholder responses to resources can be cognitive, emotional or motivational and help to explain the decisions stakeholders make about taking action (or not) ${ }^{(46)}$. It is the dynamic interaction between how contexts shape the manner in which stakeholders respond to the resources on offer from the intervention - the mechanism - that leads to a wide variety of outcomes. For the current study, we define outcomes as effects of an intervention resource, whether intended, 
Table 1 Context + mechanism $\rightarrow$ outcome hermeneutic in realist evaluation

\begin{tabular}{|c|c|c|c|}
\hline & Context & Mechanism & Outcome \\
\hline Definition & $\begin{array}{l}\text { Components of a social system that exist } \\
\text { prior to introduction of an intervention }\end{array}$ & $\begin{array}{l}\text { Interactions between components of an intervention and } \\
\text { intervention stakeholders }\end{array}$ & $\begin{array}{l}\text { The effects of an } \\
\text { intervention resource } \\
\text { or activity }\end{array}$ \\
\hline Examples & $\begin{array}{l}\text { Cultural norms regarding appropriate } \\
\text { eating habits for children } \\
\text { Food-related infrastructure in schools, } \\
\text { such as presence or absence of food } \\
\text { preparation facilities }\end{array}$ & $\begin{array}{l}\text { School staff are motivated to make changes in what } \\
\text { children eat because they agree with the intent of the } \\
\text { nutrition intervention } \\
\text { Parents gain knowledge about how to improve children's } \\
\text { diets because they have conducted nutrition } \\
\text { assessments as part of policy implementation }\end{array}$ & $\begin{array}{l}\text { Adults take action to } \\
\text { change school food } \\
\text { environments }\end{array}$ \\
\hline
\end{tabular}

unintended, short-term, intermediate or long-term on implementation processes (i.e. whether and how people are implementing the intervention rather than whether the intervention is influencing the health of children).

To explore and identify what specific dimensions of contexts may influence school-level implementation, we asked:

1. What mechanisms influence if and how expected school-level implementers make efforts to implement?

2. What specific dimensions of context interact with these mechanisms?

Articulating these relationships can provide deeper insight into why interventions do or do not work in different contexts, offering not only leverage points at which to intervene to improve or support implementation activities but also insight into the nature of this popular school food and beverage environment intervention.

\section{Design and data collection}

A multiple case study approach was used where each case unit was defined as a $\mathrm{BC}$ school district. We used purposive sampling to select five of BC's sixty school districts for the study, including two rural and three urban districts. These five districts collectively house approximately $21 \%$ of BC's public school population. All public schools reaching kindergarten to grade 12 within each district were invited to participate.

We adopted several qualitative data collection methods as outlined in Table 2.

A.L. conducted semi-structured interviews in person and over the phone with purposefully selected health and education stakeholders and private vendors. This provided in-depth information on the relationships and interactions among stakeholders across all levels of implementation, contexts and key activities related to Guidelines implementation. Interviews lasted 30-90 min and were recorded and transcribed (by A.L.) with permission of the participant.

Questionnaires were conducted with administrators and other school-level stakeholders (teachers, other staff and parents). They were administered online, via telephone or in-person (Table 3). Questions addressed implementation processes such as respondents' level of knowledge about the Guidelines, how they had disseminated information about them to other school stakeholders, if they had engaged in collaborations with stakeholders, perceived levels of compliance and whether and how they conducted nutrient assessments of foods and beverages.

Lastly, we conducted a variety of scans exploring school websites from each district in search of food sales-related activities. Website scans of school districts and the health authorities in which they were located provided more

Table 2 Data collection strategies used by district

\begin{tabular}{|c|c|c|c|c|c|c|}
\hline Data collection strategies & $\begin{array}{c}\text { District } 1 \\
\text { urban }\end{array}$ & $\begin{array}{c}\text { District } 2 \\
\text { urban }\end{array}$ & $\begin{array}{c}\text { District } 3 \\
\text { urban }\end{array}$ & $\begin{array}{l}\text { District } 4 \text { mostly } \\
\text { rural }\end{array}$ & $\begin{array}{l}\text { District } 5 \text { mostly } \\
\text { rural }\end{array}$ & Total \\
\hline Semi-structured interviews with district staff ${ }^{\star}$ & 2 & 1 & 1 & - & - & 4 \\
\hline $\begin{array}{l}\text { Semi-structured interviews with public health } \\
\text { sector staff }\end{array}$ & 3 & 2 & $-\dagger$ & 3 & 5 & 13 \\
\hline Semi-structured interviews with vendors & 4 & 2 & - & - & - & 6 \\
\hline Event attendance & 3 & - & - & - & - & 3 \\
\hline Questionnaires $\ddagger$ & 14 & 19 & 15 & 10 & 4 & 62 \\
\hline $\begin{array}{l}\text { District and Regional Health } \\
\text { Authority context scan }\end{array}$ & Yes & Yes & Yes & Yes & Yes & - \\
\hline School website scan & 10 & 12 & 10 & 17 & 13 & 62 \\
\hline
\end{tabular}

${ }^{*}$ One semi-structured interview was also conducted and included in the analysis with the sole person at the British Columbia Ministry of Education who has the Guidelines as part of their portfolio.

†Because districts 2 and 3 were in the same health authority region, the interviews with health sector staff from this health authority were used for the analysis of both districts.

$\ddagger$ There were also ten additional questionnaires where the specific district of the respondent was not identified. Comments broadly related to Guidelines implementation influenced interpretation. 
Implementation of BC's school food policy

1463

Table 3 Questionnaires completed by district and school type

\begin{tabular}{|c|c|c|c|c|c|c|}
\hline & $\begin{array}{l}\text { District } 1 \\
\text { (urban) }\end{array}$ & $\begin{array}{c}\text { District } 2 \\
\text { (urban) }\end{array}$ & $\begin{array}{c}\text { District } 3 \\
\text { (urban) }\end{array}$ & $\begin{array}{c}\text { District } 4 \\
\text { (mostly } \\
\text { rural) }\end{array}$ & $\begin{array}{c}\text { District } 5 \\
\text { (mostly } \\
\text { rural) }\end{array}$ & $\begin{array}{l}\text { Unknown } \\
\text { district* }\end{array}$ \\
\hline \multicolumn{7}{|c|}{ Respondent type } \\
\hline Parent & 12 & 7 & 2 & 1 & - & - \\
\hline Administrator & & 11 & 13 & 9 & 4 & 1 \\
\hline $\begin{array}{l}\text { School food } \\
\text { staff }\end{array}$ & 2 & - & - & - & - & 3 \\
\hline Teacher & - & - & - & - & - & 1 \\
\hline Unknown & - & 1 & - & - & - & 5 \\
\hline Total & 14 & 19 & 15 & 10 & 4 & 9 \\
\hline
\end{tabular}

${ }^{*}$ Respondent did not specify district.

context regarding organisational structures, whether explicit, accessory healthy school food policies had been created by school districts, and amount of information available about school food and nutrition. Also, we scanned the websites of private vendors who participated in the study for more information about their products. Website data were organised in a table and incorporated into case memos created for each school district as described below.

\section{Analysis}

Interview transcripts and long-answer portions of the questionnaires were open coded using qualitative analysis software ${ }^{(47)}$. Influenced by an initial program theory developed in an earlier phase of this research and published elsewhere $^{(48)}$, we used a linked CMO coding technique ${ }^{(49)}$ which involved identifying an implementation outcome described in the data, then reading for the respondent's explanation as to how this outcome came about. When describing an event or occurrence, participants often naturally described relationships between contexts, mechanisms and outcomes. The contexts, mechanisms and outcomes identified in a portion of narrative were assigned a linked code (e.g. C24-M10-O23). Memos were created for each district, including their associated linked CMO coded data and the information collected from the website scans. A within and across case analysis was conducted through these memos. This helped to distill how the different contexts of each district may have been influencing mechanisms at the school level, leading to diverse or similar outcomes across schools.

\section{Results}

Study participants' observations and experiences working with and/or as school-level stakeholders provided explanatory insight about social processes influencing implementation of the BC Guidelines. Four key mechanisms were identified that interact with specific dimensions of context to trigger stakeholders to engage or not engage in implementation-related activities: (i) mandatory mechanism; (ii) scofflaw mechanism ${ }^{1}$; (iii) economic mechanism and (iv) resource constraint mechanism.

\section{Mandatory and scofflaw mechanisms: divergent responses to the same intervention}

Although the BC government declared its food and beverage policy to be mandatory, it did not enact official monitoring or enforcement measures. This mandatory directive led to two different responses among expected implementers. First, this mandate triggered some stakeholders, such as administrators, to engage in implementation-related activities. These administrators explained their desire to be seen to be abiding by the rules. On the other hand, for other expected-implementers, including some teachers and parents involved in fundraising, the 'mandatory' resource triggered a 'scofflaw' mechanism, whereby forms of resistance emerged such as ignoring the mandate or finding ways to avoid it. We identified specific dimensions of context that could be influencing these contrasting responses.

\section{Mandatory mechanism}

British Columbia is a context where the education system is relatively hierarchical, whereby districts are broadly directed by the provincial ministry and districts direct school administrators, who in turn play an important role in determining the functioning of their school. There were many examples of school-level stakeholders making efforts to implement the Guidelines in response to the mandatory nature of the Guidelines. They were compelled towards making efforts to implement the Guidelines because it was seen as a directive from the province and participants acting at the school district level pointed to this mechanism as being an important driver of implementation. Four of the five school district websites had explicit statements about compliance to the provincial Guidelines in their district health and wellness

'Scofflaw' refers to people who feel resistance to authoritative directives because they do not agree with being told what to do (especially by a government). They may respond by ignoring directives altogether or act in ways meant to openly exhibit their resistance, flouting the directive in defiance ${ }^{(59)}$. 
Table 4 Context + mechanism $\rightarrow$ outcome configurations for the mandatory mechanism

\begin{tabular}{|c|c|c|c|}
\hline Context & $\begin{array}{l}\text { Mechanism } \\
\text { (resource + reasoning) }\end{array}$ & Outcome & Example quote \\
\hline $\begin{array}{l}\text { The education system } \\
\text { is hierarchical }\end{array}$ & $\begin{array}{l}\text { Mandatory directive from } \\
\text { the district motivates } \\
\text { school principals, as } \\
\text { part of their job }\end{array}$ & $\begin{array}{l}\text { Administrators encourage, support, } \\
\text { and/or mandate school staff, } \\
\text { students and parent volunteers, } \\
\text { to implement the Guidelines when } \\
\text { fundraising with food }\end{array}$ & $\begin{array}{l}\text {.. We get told all the time that we better } \\
\text { be following it and otherwise we'll get } \\
\text { in trouble-the district guy threatens } \\
\text { us... (Administrator, SD 4) } \\
\text { Students have to come present to us } \\
\text { what they're selling and the timelines. } \\
\text { We tell them they need to meet the } \\
\text { Guidelines. (Administrator, SD 2) }\end{array}$ \\
\hline $\begin{array}{l}\text { The education system } \\
\text { is hierarchical } \\
\text { AND } \\
\text { Beliefs of some or all of the } \\
\text { school-level stakeholders } \\
\text { align with the intention of } \\
\text { the Guidelines }\end{array}$ & $\begin{array}{l}\text { Mandatory directive from } \\
\text { administrator bolsters } \\
\text { motivation of other } \\
\text { school-level } \\
\text { stakeholders }\end{array}$ & $\begin{array}{l}\text { Efforts are made to comply by } \\
\text { school-level implementers (e.g. } \\
\text { by parents, staff, students) }\end{array}$ & $\begin{array}{l}\text { When all players are on the same page- } \\
\text { striving for common goal-gave me } \\
\text { that ability to push forward with } \\
\text { implementation. (Administrator, SD 4) }\end{array}$ \\
\hline $\begin{array}{l}\text { Administrator has strong } \\
\text { relationship with Parent } \\
\text { Advisory Council } \\
\text { AND } \\
\text { Administrator perceives } \\
\text { Parent Advisory Council } \\
\text { has sufficient capacity }\end{array}$ & $\begin{array}{l}\text { Mandatory directive from } \\
\text { the district compels } \\
\text { school principals, as } \\
\text { part of their job }\end{array}$ & $\begin{array}{l}\text { Administrators encourage, support } \\
\text { and/or mandate parent volunteers } \\
\text { to implement the Guidelines when } \\
\text { fundraising with food }\end{array}$ & $\begin{array}{l}\text { I think that stems from having a good } \\
\text { relationship with your parent group } \\
\text { and your PAC. I know our PAC is } \\
\text { fantastic and always very respectful. } \\
\text { They always consult with me on food } \\
\text { ideas. (Administrator, SD 1) }\end{array}$ \\
\hline
\end{tabular}

policies. Guidelines compliance appeared to have become part of school administrators' jobs.

The influence of the mandatory directive was clear in one particular example where an administrator reported their own beliefs that were aversive to the Guidelines, saying "[the Guidelines] are targeting the wrong audience... it is just the Ministry trying to cover their butts because of the obesity issue in Canada' (Administrator, SD 4). Regardless of this personal aversive belief, the administrator reported a relatively high level of engagement in implementation activities so as to avoid being reprimanded by district staff.

As a result of the mandate, the pressure to implement trickled down from the administrator, triggering some school-level stakeholders to accept the intervention and make efforts towards implementation. Regarding their parent advisory council (PAC), which was often involved in food fundraising, one administrator stated: '[The PAC] came around and realised ....that was just how it was going to be...' (Administrator, SD 1). There was a unique dynamic between administrators and PAC members who volunteered for fundraising efforts (primarily in elementary schools), but were not under the 'authority' of the school principal through employment or by being in the subordinate position of students. Two important components of context were reported to influence how much pressure elementary school administrators put on PACs to comply with the Guidelines in their fundraising efforts: the quality of their relationship and the administrator's perception of the PACs capacity. If the PAC was perceived to have sufficient capacity and there was a positive relationship with their PACs, administrators reported feeling able to exert more top-down pressure.
School stakeholders' pre-existing beliefs about food and health formed another contextual influence affecting their responses to the mandatory directive. While strong beliefs about the importance of nutrition were not essential for driving engagement in implementation activities, existence of 'passionate parents' (Administrator, SD 1) or teachers whose pre-existing beliefs aligned with an administrator's intent to comply with the policy directive were perceived as helping bolster implementation efforts in some schools.

The relationships of mandatory mechanism with contexts and outcomes are summarised in Table 4.

\section{Scofflaw mechanism}

While the mandatory mechanism compelled some expected implementers to engage in implementation activities, there were other expected implementers (e.g. some parents and/or teachers) who reportedly responded to the mandatory directive with feelings of aversion to being told what to do. This drove them to either ignore the Guidelines or continue with business-as-usual (i.e. continue selling the types of items they have always sold, many of which are categorised as 'sell never' by the Guidelines), or find ways to skirt around the Guidelines. Sometimes these expected implementers would devise means by which to technically comply but that were counter to the intent of the Guidelines, including continuing to sell popular items for fundraisers that did not meet the Guidelines but sell them to parents instead of students; selling items to students that technically complied with the nutrient criteria due to their size but it was likely students would probably purchase more than one (e.g. baked goods, a slice of pizza) and selling an item for a fundraiser that complied, 
Table 5 Context + mechanism $\rightarrow$ outcome configurations for the scofflaw mechanism

\begin{tabular}{|c|c|c|c|}
\hline Context & Mechanism (resource + reasoning) & Outcome & Example quote \\
\hline $\begin{array}{l}\text { Elementary school-level stakeholders } \\
\text { are often responsible for organising } \\
\text { external hot lunch vendors and } \\
\text { other food sales for fundraising } \\
\text { AND } \\
\text { These school-level stakeholders hold } \\
\text { pre-existing beliefs that may not } \\
\text { align with the intent of the } \\
\text { Guidelines } \\
\text { AND/OR } \\
\text { Inconsistent implementation and } \\
\text { enforcement are observed by } \\
\text { school-level stakeholders }\end{array}$ & $\begin{array}{l}\text { The top-down mandate and } \\
\text { knowing there are no } \\
\text { repercussions for non-compliance } \\
\text { leads some school-level } \\
\text { stakeholders to have averse } \\
\text { feelings towards the Guidelines }\end{array}$ & $\begin{array}{l}\text { They may choose to } \\
\text { not make efforts } \\
\text { to implement } \\
\text { (Outcome A) } \\
\text {.. and/or they may } \\
\text { choose to 'skirt' } \\
\text { around the } \\
\text { Guidelines } \\
\text { (Outcome B) }\end{array}$ & $\begin{array}{l}\text {.. then when we have sales, we } \\
\text { have milk and cookie day-so we'll } \\
\text { sell the milk and give the cookies } \\
\text { out-that is an example of when } \\
\text { people get pushed. (Administrator, } \\
\text { SD 4) } \\
\text {.. it's too rigid. 'Therefore, you have } \\
\text { to do this.' Then people get turned } \\
\text { off because you're being pushed } \\
\text { to do it... (Dietitian) }\end{array}$ \\
\hline
\end{tabular}

such as milk, with an accompanying 'free' cookie that did not technically fall within the reach of the Guidelines because it is not being sold. These antithetical activities were further enabled because of the absence of official enforcement measures at the provincial and district levels. Only a quarter of questionnaire respondents reported that food fundraisers 'always' complied with the policy in their schools.

Several contextual factors influenced stakeholders' aversion to the mandatory nature of the Guidelines and their subsequent lack of engagement in implementation activities. First, fundraising was often seen as key to providing a well-rounded education experience in the context of perceived public school underfunding. School website scans showed that fundraising conducted by teachers was typically directed at supporting student clubs and PAC fundraising profits supported items such as educational supplies, guest speakers and performances, wellness workshops for students, playground equipment and school gardens. These expected implementers were resistant to being told they must change how they fundraise in a way they believed would decrease profits.

... it's a lot about making money. I know people on the PAC and they've ordered [a sugary drink] for the events and it was like, 'well it was 25 cents a liter at [the store] and how could we pass that up'. And then they're selling stuff for sports day and they try to have some healthy stuff but [at the same time] they're like 'well we have to [also] have some jumbo [frozen sugary treats] because ... we have to make some money!'. (Dietitian and parent)

Second, some people's pre-existing beliefs around the role of government in society may not align with this type of intervention instrument (i.e. a mandate), causing an aversive reaction to this 'draconian imposition of someone else's values' (Administrator, SD 1). Third, pre-existing beliefs about food in general and food in schools, specifically, may not align with the content of the Guidelines, such as beliefs that children will not eat (or purchase) healthy options, that they deserve to have treats at school, that treats do not happen often at school and that children require larger portion sizes than those that comply with the Guidelines. Fourth, inconsistent compliance of the Guidelines either between venues in a school or between schools, which was reported to often be the case, resulted in perceptions of 'unfairness'. One dietitian spoke about experiences where parents from one school sometimes noticed other schools within their district not complying and, in turn, responded with the question of "well why are we trying so hard?...' (Dietitian).

The CMO configuration associated with the scofflaw mechanism are summarised in Table 5.

\section{Economic mechanism: created demand leads to supply creation}

School-level efforts to comply with the Guidelines created a demand for private food vendors to provide compliant food and beverage options. From a realist perspective, this demand can be considered as an 'intervention resource' to which vendors respond. School-level hot lunch fundraisers were reported as occurring rarely in secondary schools but anywhere from once per month to once or twice per week in elementary schools. Respondents described how some vendors would only present offerings that complied; otherwise, they risked being excluded from selling their products in schools:

No [vendor] is going to bring you a product that doesn't meet the Guidelines because you would just strike them off right away. (Administrator, SD 1)

Participants identified two types of hot lunch fundraiser vendors who complied with the Guidelines in different ways - franchised fast food restaurants and small business hot food vendors. Respondents from all the districts, website scans and observations at public events confirmed that fast food restaurants were an important source in fundraising. The data collected from promotional brochures, observations and informal conversations at public events in urban districts showed some restaurants had reformulated items to comply with the Guidelines. For example, in informal discussions with pizza franchises attending public events related to school food, they described 
creating pizzas topped with less cheese to comply with the fat criteria in the Guidelines. As one small pizza franchise stated in their information sheet for school-level stakeholders:

[We are] pleased to offer our Hot Lunch Program which follows the Guidelines for Food and Beverage Sales required by the BC Ministries of Health and Education. As a result, [we] are featured in the [BC Ministry of Health's] Brand Name Food List, the list that approves ready-to-eat, packaged, and franchised foods. (Vendor information sheet provided at public event)

School-level respondents also stated that their providers were reformulating their offerings, such as re-creating submarine sandwiches from their menu meant for the general population that had less salty, sugary and/or fatty condiments. This reformulating allowed PACs to provide options for students that both complied with Guidelines while also fulfilling a desire to provide what were classically considered 'fun foods'. This was also perceived (by parents and administrators) to help ensure students would be interested in purchasing these items, generating higher profits for fundraising.

In urban areas, in addition to the fast food franchises, small-business hot lunch vendors were also engaged in supplying food offerings for PAC hot lunch fundraisers. These vendors promoted their offerings as not only meeting the Guidelines but also as being diverse, made by hand using whole foods, and as being healthier. These vendors were reported as being motivated not only by a sustainable income but also by their desire to contribute to a healthy, diverse food culture. Even when asked to reduce their prices by PAC members, one vendor reported they would never reduce the quality of product to maintain their bottom line but rather would renegotiate the price. Another vendor reported they used their philosophy about nutritious food to determine with whom they would work, gently refusing to work with PACs who did not share their whole-foods, healthy food philosophy. This suggests vendor beliefs were important in determining what kinds of offerings they provided and how these beliefs can even override profit motivations. These vendors' compliance may not have been fully related to the existence of the Guidelines, unlike some of the fast-food restaurants, as their whole foods, less-processed products reportedly complied without much effort. There was some evidence to suggest, though, that the existence of the mandatory nutrition standards provided vendors clout to back up their principles when dealing with school stakeholders asking for 'hot dog days' and 'regular chocolate milk' (as opposed to the reduced sugar version) (Vendor SD 3).

The CMO configurations associated with the economic mechanism are shown in Table 6.

\section{Resource constraint mechanism}

Some expected school-level implementers were motivated to change the food environment but felt they did not have the capacity to do so due to lack of human resources, lack

Table 6 Context + mechanism $\rightarrow$ outcome configurations for the economic mechanism

\begin{tabular}{|c|c|c|c|}
\hline Context & $\begin{array}{l}\text { Mechanism } \\
\text { (resource + reasoning) }\end{array}$ & Outcome & Example quote \\
\hline $\begin{array}{l}\text { Owners of franchises that offer } \\
\text { conventional school food have } \\
\text { a pre-existing drive to sustain } \\
\text { their business }\end{array}$ & $\begin{array}{l}\text { The Guidelines are specific } \\
\text { nutrient criteria and the } \\
\text { demand by school } \\
\text { stakeholders to comply with } \\
\text { the mandatory Guidelines } \\
\text { incentivises vendors }\end{array}$ & $\begin{array}{l}\text { Items are compliant but are } \\
\text { reformulated to mimic } \\
\text { conventional school food }\end{array}$ & $\begin{array}{l}\text { We work with a local pizza place } \\
\text { and it is one of our infrequent } \\
\text { yellow items- last month the } \\
\text { PAC did a pizza day and we } \\
\text { work with them-we work with } \\
\text { Booster Juice- we also work } \\
\text { with Quiznos- they've done } \\
\text { their homework that we are } \\
\text { happy to buy and sell to kids. } \\
\text { (Administrator, SD 5) }\end{array}$ \\
\hline $\begin{array}{l}\text { Small hot lunch vendors (at least } \\
\text { in urban areas) have a pre- } \\
\text { existing drive to sustain their } \\
\text { business. Some small hot } \\
\text { lunch vendors also have pre- } \\
\text { existing beliefs supporting } \\
\text { healthy, diverse foods and } \\
\text { changing food culture }\end{array}$ & $\begin{array}{l}\text { These vendors are motivated by } \\
\text { their own value system, } \\
\text { regardless of the existence of } \\
\text { the Guidelines, to provide } \\
\text { healthy and delicious options } \\
\text { and the nutrient criteria of the } \\
\text { Guidelines provides them the } \\
\text { information needed to align } \\
\text { their products with mandated } \\
\text { expectations }\end{array}$ & $\begin{array}{l}\text { They create hot lunch offerings } \\
\text { that are interesting, healthy, } \\
\text { diverse, prepared using } \\
\text { whole foods that comply with } \\
\text { the Guidelines }\end{array}$ & $\begin{array}{l}\text { The whole idea of the [company] } \\
\text { is that we wanted to make } \\
\text { everything from scratch .... but } \\
\text { also, number two, to have an } \\
\text { ethnically diverse menu.... } \\
\text { think kids should be exposed } \\
\text { to a wide variety of different } \\
\text { types of foods... (Hot lunch } \\
\text { vendor (A), SD 3) } \\
\text { So, and my job is to provide } \\
\text { things that are... from } \\
\text { scratch... which removes a lot } \\
\text { of the Guideline issues... but } \\
\text { something that tastes } \\
\text { good... I know that they're } \\
\text { getting some nutrition and } \\
\text { protein so they can learn well. } \\
\text { (Hot lunch vendor (B), SD 3) }\end{array}$ \\
\hline
\end{tabular}


of access to items that comply and/or the higher cost of compliant items. Because the Guidelines do not offer intervention resources to address these capacity issues, some implementers may have been de-motivated and ultimately were not making efforts to implement.

In particular, elementary schools have a high dependence on volunteers which resulted in, in some cases, concerns about the human resources capacity in schools. This concern was related to the level of parent engagement as well as the transient nature of PACs. One administrator described having a high level of implementation engagement in a previous school with a PAC that desired change. However, a transfer to another school with very few engaged parents left them with decreased motivation and power to move towards implementation. Regarding the transiency of PACs, once children graduate and move to a different school, parents leave with them. There is no guarantee that when one engaged parent leaves, another equally engaged parent will come on board to replace them. When human resources were a concern, even motivated parents aimed to find the most convenient ways to conduct food fundraising, often reportedly leading them to sell unhealthy items.

In addition to the human resource issues, lack of food preparation infrastructure and, in rural areas, the lack of private vendor options were additional resource constraints restricting implementation of the Guidelines. While all urban and some rural secondary schools were reported as having a cafeteria with ample food service infrastructure, most elementary schools across all districts lacked food preparation and food storage facilities. Urban areas had access to numerous options for external vendors, but in the rural districts, access was more limited to fast-food franchises and small family-owned private restaurants or convenience stores from which school-level stakeholders could purchase items to then sell in their schools.

We have one vendor [in our community] that [can reach] our Guideline goals.... [and] that is in our price range with desirable offerings for the kids. So, we choose to [also] use other vendors and not follow the Guidelines ... fully aware that we are not following them because it is just not possible to [always] provide the food items we would like with the restrictions that have been put in place. (PAC member and dietary technologist, SD 4)

Lastly, capacity related to the cost of nutritionally compliant items was reported by some administrators and parents. This is associated with the overall context of the need for schools to fundraise; food fundraising input cost must be as low as possible to ensure the highest possible profit. Some schools reported that they did not have sufficient financial resources to provide healthy free or subsidised options and instead sought to fundraise with offerings they believed would sell well and required the lowest financial input (e.g. cheap, processed items).

The CMO configurations associated with the resource constraint mechanism are shown in Table 7.

Table 7 Context + mechanism $\rightarrow$ outcome configurations for the resource constraint mechanism

\begin{tabular}{|c|c|c|c|}
\hline Context & $\begin{array}{l}\text { Mechanism (resource (or lack } \\
\text { thereof) }+ \text { reasoning) }\end{array}$ & Outcome & Example quote \\
\hline $\begin{array}{l}\text { Administrator's quality of } \\
\text { relationship with PAC } \\
\text { members is less than } \\
\text { collaborative/ } \\
\text { consistent } \\
\text { School administrator's } \\
\text { perception of PAC } \\
\text { capacity is low }\end{array}$ & $\begin{array}{l}\text { Mandatory directive from the } \\
\text { district/top-down pressure to } \\
\text { implement the Guidelines in } \\
\text { schools is not sufficient to trigger } \\
\text { action as the administrator is } \\
\text { motivated to maintain a positive } \\
\text { relationship with parent } \\
\text { volunteers }\end{array}$ & $\begin{array}{l}\text { Administrators may feel reluctant } \\
\text { to engage with parent } \\
\text { volunteers about compliance } \\
\text { resulting in less efforts made to } \\
\text { meet the Guidelines }\end{array}$ & $\begin{array}{l}\text {.. it was easier for me to shut the } \\
\text { canteen down than to try and } \\
\text { make that switch in the } \\
\text { community-l've got such a small } \\
\text { school-we're having more single } \\
\text { parents or more parents working } \\
\text { so they're not available either to } \\
\text { come in and take this kind of thing } \\
\text { on. (Administrator, SD 5) }\end{array}$ \\
\hline $\begin{array}{l}\text { School-level } \\
\text { stakeholders are } \\
\text { motivated to create } \\
\text { health maximising } \\
\text { opportunities for } \\
\text { children } \\
\text { BUT... } \\
\text { lack time, infrastructure } \\
\text { and financial capacity }\end{array}$ & $\begin{array}{l}\text { The Guidelines, as an intervention, } \\
\text { do not provide financial, material } \\
\text { or human resources in schools } \\
\text { nor any official enforcement } \\
\text { mechanisms and so school-level } \\
\text { implementers feel constrained }\end{array}$ & $\begin{array}{l}\text { Choosing to continue on with } \\
\text { business-as-usual school food } \\
\text { and beverage sales offerings } \\
\text { may not comply with } \\
\text { Guidelines }\end{array}$ & $\begin{array}{l}\text { It's totally efficiency because I did try } \\
\text { to bring in... watermelon on } \\
\text { sports day and... immediately it } \\
\text { was like 'I am not going to spend } \\
\text { my time slicing off } \\
\text { watermelon'.... .everyone was all } \\
\text { up in arms about how much work } \\
\text { this was going to be [laughs]. I } \\
\text { was like 'are you kidding me? It } \\
\text { will take like } 20 \text { minutes! (Dietitian } \\
\text { and parent, SD 1) } \\
\text {... it would be nice just to have fresh } \\
\text { local healthy food. But it is also the } \\
\text { practicality of doing that... most of } \\
\text { the schools [in the district] do not } \\
\text { have kitchens in their school. } \\
\text { (Dietitian and parent, SD 1) }\end{array}$ \\
\hline
\end{tabular}




\section{Discussion}

The current study adopted a realist approach to provide a nuanced explanation of why and how barriers and facilitators lead to challenges and successes with implementation. Our findings identify key mechanisms influencing schoollevel implementers' engagement with a school food and beverage policy and highlight how these mechanisms are expressed differently in various contexts.

As found in other studies ${ }^{(15,32)}$, the mandatory nature of the Guidelines motivates some school-level stakeholders towards implementation. Friedman ${ }^{(50)}$ argues that the public are likely to be more amenable to authoritarian interventions, such as mandates, when (i) children are involved and (ii) they are rolled-out in contexts that are already viewed as, and accepted as, paternalistic settings. Reflecting this, studies from North American jurisdictions find parents and teachers - in theory - overwhelmingly support limiting unhealthy foods in schools through policy ${ }^{(51,52)}$. However, our study and others ${ }^{(30-32,53,54)}$ have found that this is not necessarily the case in practice, as some stakeholders (particularly parents and teachers) were reported to take limited or no actions to implement school nutrition policies because of their aversion to the paternalistic nature of mandatory interventions. This reported aversion to interventions meant to support children's health is contrary to the normative ideal that adults are concerned with maximising children's welfare. This contradiction may be influenced by other contextual features: ${ }^{(55)}$ as expected implementers face various structural barriers to carrying out this duty imposed on them by a government mandate, they experience constrained choice ${ }^{(56-58)}$, which has been found to trigger aggression, non-cooperation ${ }^{(58,59)}$ and lower productivity ${ }^{(60)}$, which may be manifesting as aversion to the paternalistic nature of the intervention.

Regarding private vendors, there is a paucity of literature addressing motivations and beliefs of private vendors that supply school food. Scott, Hawkins and Knai ${ }^{(61)}$ called into question the intentions of food industry actors, suggesting that reformulation of products to meet nutrient criteria is simply a corporate political/survival strategy. Our findings suggest that, for at least some local and regional smaller private vendors, personal commitment to food and health supported their compliance with the mandatory government policy. For all stakeholder groups, further exploration of how personal commitments to food and health relate to efforts to implement school food Guidelines is warranted, including examination of how that relationship varies among school volunteers, employees and suppliers.

It is often perceived that nutrition standards make it difficult to have profitable fundraisers as the standards limit what can be sold. However, our findings suggest that this may be an over-simplification of this barrier and that it is also closely linked with pre-existing beliefs about both school food and food in general. First, we found the belief in the narrowness of children's food preferences (and therefore what they will purchase) appears to influence decisions around what foods and beverages will be sold, as also reported in another Canadian study ${ }^{(30)}$. Our research adds to this by elucidating other beliefs that may be influencing these decisions, including that (i) children are entitled to treats and (ii) the portion sizes resulting from attempts to limit salt, sugar and fat are insufficient. The first of these two beliefs may be founded on deeply embedded normative beliefs about (i) children's entitlement to a 'joyful' (62, p. 27) ${ }^{2}$ childhood that necessarily includes treats and (ii) the social meanings of food transactions between parent (and perhaps other types of caregivers) and child and what provision of a treat may symbolise ${ }^{(63,64)}$. Regarding beliefs about portion sizes, the findings suggest that when parent volunteers select options for fundraising that meet the nutrient criteria but believe the portion sizes are insufficient, they increase portion sizes, resulting in non-compliance. One possible explanation for this demand for larger, non-compliant portions is that it is an unintended consequence of BC's Guidelines being nutrient-based criteria with no parameters around serving sizes (i.e. criteria are measured per portion or serving size rather than per $100 \mathrm{~g}$, for example). Because vendors can reformulate to comply with the nutrient criteria for salt, sugar and fat rather than, for example, criteria based on whole foods, it is possible to simply produce smaller versions of the same kinds of items they were selling prior to the nutrient criteria to be compliant. These, however, may not be of sufficient size to satisfy appetites.

As reported in other Canadian contexts ${ }^{(29,31,65,66)}$, some school-level stakeholders reported wanting to engage in implementation but believed they lacked the resources to do so, resulting in not making the effort to implement at all. The frustration expressed by these stakeholders may have contributed to an experience of moral distress that occurs when a person knows the right thing to do, but institutional constraints make it nearly impossible to $\mathrm{act}^{(67)}$. Literature on moral distress specific to healthcare practitioners has found that the experience of moral distress can lead to 'burnout' ${ }^{\text {(68) }}$, cynicism and low efficacy ${ }^{(69)}$. Our findings suggest that this concept may also be useful when considering implementation of public health policies and programs.

Finally, the findings reported here focus on school-level stakeholders. In another component of the same study, we examined key mechanisms influencing district-level implementers' engagement with the same policy ${ }^{(44)}$. There were some similarities in mechanisms apparent at the two levels, particularly regarding the mandatory nature of the policy and the motivations and involvement of private vendors. However, the dynamics of how these mechanisms played out differed between the school- and district-level actors. At the district level, the mandatory nature of the Guidelines resulted in responsibility for implementation being added to specific job responsibilities, with differences in how this was handled between rural and urban districts. Perhaps 
because of this incorporation of responsibilities into job descriptions, there was no evidence of people avoiding or skirting implementation actions. Regarding interactions with private vendors, district-level stakeholders were involved in urban but not rural districts, where they worked with large private vendors through district-wide procurement contracts. As with the smaller vendors who worked with school-level vendors as described in this paper, there were two main types of vendors: those who focused on providing compliant, reformulated versions of conventional school food and those who offered a variety of diverse, healthy menu choices. The resource constraint mechanism described in this paper appears to be unique to the school level.

\section{Conclusion}

The current study aimed to contribute to a nuanced understanding of social processes influencing implementation of a complex school food environment intervention: what are the interactions between pre-existing contexts and mechanisms and how do these lead implementers to make decisions around if or how they will engage with implementation. The mandatory nature of the policy has both positive and inhibitory effects at the school level, with some stakeholders taking actions to implement the Guidelines because of cascading expectations for action being passed from the provincial government to the school district to the school administrator to teachers, staff and students. Towards the bottom of this cascade, however, some stakeholders - particularly those whose compliance is based solely on personal commitment and motivation rather than a responsibility of their employment - resist partial or full participation and express aversion to being told what to do by the government. In many rural schools and urban elementary schools, much of the food and beverage sales are managed by volunteers, usually with very little financial or physical infrastructure support. The nature of the relationship between school administrators and these volunteers is such that administrators can try to motivate and support implementation of the Guidelines, but their success in this is limited by the capacity of the volunteers and available infrastructure. In contexts where there are a number of food vendors, competition can lead to availability of compliant products. However, in rural contexts with few vendors, procurement of compliant products can be difficult.

\section{Acknowledgements}

Acknowledgements: The authors would like to acknowledge the British Columbia Ministry of Education and the British Columbia Ministry of Health staff who supported this research through their willingness to participate both in interviews and in respondent verification. The authors would also like to thank the British Columbia Regional Health Authority dietitians, various school district staff and private sector vendors for giving their time to participate in interviews. Lastly, the authors would like to acknowledge Dr. Jim Frankish and Dr. Jennifer Black for their support throughout the research process. Financial support: A.L. is supported by the Canadian Institutes of Health Research's Fredrick Banting and Charles Best Canada Graduate Scholarship Doctoral Award (UBC Award No. 6557) and the University of British Columbia's Four Year Fellowship Award (UBC Award No. 6569, 6456). Funders had no role in the design, analysis or writing of this article. Conflict of interest: None. Authorship: A.L. and G.C. derived the research idea. All authors contributed to the development of the research process. A.L. conducted the analysis and prepared the manuscript. G.C., B.S. and H.W. all contributed in-depth intellectual input for the development of the manuscript. Ethics of human subject participation: The current study was conducted according to the Guidelines laid down in the Declaration of Helsinki, and all procedures involving human subjects/patients were approved by the University of British Columbia's Human Research Ethics Board. Written informed consent was obtained from all participants.

\section{References}

1. Rokholm B, Baker JL \& Sorenson TIA (2010) The levelling off of the obesity epidemic since the year 1999 - a review of evidence and perspectives. Obes Rev 11, 835-846.

2. Wang Y, Beydoun MA, Liang L et al. (2008) Will all Americans become overweight or obese? Estimating the progression and cost of the US obesity epidemic. Obesity 16, 2323-2330.

3. Withrow D \& Alter DA (2011) The economic burden of obesity worldwide: a systematic review of the direct costs of obesity. Obes Rev 12, 131-141.

4. High Level Panel of Experts (HLPE) (2017) Nutrition and Food Systems. A Report by the High Level Panel of Experts on Food Security and Nutrition of the Committee on World Food Security. Rome: Food and Agriculture Organization of the United Nations.

5. Centers for Disease Control and Prevention (CDC) (2012) Competitive Foods and Beverages in U.S. Schools: A State Policy Analysis. Atlanta, USA: U.S. Department of Health and Human Services

6. Antilla J, Rytkonen T, Kankaanpaa R et al. (2015) Effect of national recommendation on sweet selling as an intervention for a healthier school environment. Scand J Public Health 43, 27-34.

7. Bonsmann SSG, Kardakis T, Wollgast J et al. (2014) Mapping of National School Food Policies Across the EU28 Plus Norway and Switzerland. Italy: European Commission Joint Research Centre.

8. Carriere C, Lorrain S, Langevin C et al. (2015) Impact d'une intervention sur l'offre alimentaire et sur les comportements alimentaires des adolescents (hors restauration scolaire) (Impact of an intervention improving the food supply (excluding school meals) with educational support in middle and high schools). Arch Pédiatrie 2015, 1223-1232.

9. Holmes S (2016) What's for lunch? Identifying and comparing subnational jurisdictional approaches to school nutrition regulations in English-speaking Canada. Doctoral Dissertation, University of Guelph. 
10. Holthe A, Larsen T \& Samdal O (2010) The role of physical structures in implementing the Norwegian guidelines for healthy school meals. Health Place 16, 93-100.

11. Mensink F, Schwinghammer SA \& Smeets A (2012) The healthy school canteen programme: a promising intervention to make the school food environment healthier. J Environ Public Health 2012, 1-8.

12. Monterrosa EC, Campirano F, Tolentino Mayo L et al. (2015) Stakeholder perspectives on national policy for regulating the school food environment in Mexico. Health Policy Plan 30, 28-38.

13. Nathan N, Yoong SL, Sutherland R et al. (2016) Effectiveness of a multicomponent intervention to enhance implementation of a healthy canteen policy in Australian primary schools: a randomised controlled trial. Int J Behav Nutr Phys Act 13, 1-9.

14. Dick M, Lee A, Bright M et al. (2012) Evaluation of implementation of a healthy food and drink supply strategy throughout the whole school environment in Queensland state schools, Australia. Eur J Clin Nutr 66, 1124-1129.

15. Hills A, Nathan N, Robinson K et al. (2015) Improvement in primary school adherence to the NSW Healthy School Canteen Strategy in 2007 and 2010. Health Promot J Austr 26, 89-92.

16. Pettigrew S, Pescud M \& Donovan RJ (2012) Outcomes of the West Australian school healthy food and drink policy. Nutr Diet 69, 20-25.

17. Nanney MS, Davey CS \& Kubik MY (2013) Rural disparities in the distribution of policies that support healthy eating in US secondary schools. J Acad Nutr Diet 113, 1062-1068.

18. Gorski MT, Cohen JFW, Hoffman JA et al. (2016) Impact of nutrition standards on competitive food quality in Massachusetts middle and high schools. Am J Public Health 106, 1101-1108

19. Kubik MY, Wall M, Shen L et al. (2010) State but not district nutrition policies are associated with less junk food in vending machines and school stores in US public schools. $J$ Am Diet Assoc 110, 1043-1048.

20. Watts AW, Masse LC \& Naylor P-J (2014) Changes to the school food and physical activity environment after guideline implementation in British Columbia, Canada. Int J Behav Nutr Phys Act 11, 10.

21. Ohri-Vachaspati P, Turner L \& Chaloupka FJ (2012) Alliance for a healthier generation's competitive beverage and food guidelines: do elementary school administrators know about them and do they report implementing them? J Sch Health 82, 469-477.

22. Taber DR, Chriqui JF, Powell LM et al. (2015) Socioeconomic differences in the association between competitive food laws and the school food environment. $J$ Sch Health $\mathbf{8 5}$, 578-586.

23. Kubik MY, Davey C, Nanney MS et al. (2013) Vending and school store snack and beverage trends: Minnesota secondary schools, 2002-2010. Am J Prev Med 44, 583-588.

24. Kubik MY, Davey C, MacLehose RF et al. (2015) Snacks, beverages, vending machines, and school stores: a comparison of alternative and regular schools in Minnesota, 2002 to 2008. J Acad Nutr Diet 115, 101-105.

25. Samuels SE, Hutchinson KS, Craypo L et al. (2010) Implementation of California state school competitive food and beverage standards. $J$ Sch Health 80, 581-587.

26. Whatley Blum JE, Davee A-M, Devore RL et al. (2007) Implementation of low-fat, low-sugar, and portioncontrolled nutrition guidelines in competitive food venues of Maine public high schools. J Sch Health 77, 687-693.

27. British Columbia Ministry of Education (BCMoEd) \& British Columbia Ministry of Health (BCMoH) (2008) School Food Sales and Policies Provincial Report II. British Columbia, Canada: ActNowBC \& the Government of British Columbia.
28. Pawson R (2013) The Science of Evaluation: A Realist Manifesto. London: SAGE Publications Ltd.

29. Government of Manitoba (2015) Measuring Success: Series Report on Manitoba Healthy Food in Schools. Stakebolder Perceptions of School Nutrition Policy. Winnipeg, Manitoba: Government of Manitoba.

30. MacLellan D, Holland A, Taylor J et al. (2010) Implementing school nutrition policy: student and parent perspectives. Can J Diet Pract Res 71, 172-177.

31. Vine MM \& Elliott SJ (2014) Examining local-level factors shaping school nutrition policy implementation in Ontario, Canada. Public Health Nutr 17, 1290-1298.

32. Masse LC, Naiman D \& Naylor P-J (2013) From policy to practice: implementation of physical activity and food policies in schools. Int J Behav Nutr Phys Act 10, 71.

33. Han-Markey TL, Wang L, Schlotterbeck S et al. (2012) A public school district's vending machine policy and changes over a 4-year period: implementation of a national wellness policy. Public Health 126, 335-337.

34. Pettigrew S, Pescud M \& Donovan RJ (2012) Stakeholder perceptions of a comprehensive school food policy in Western Australia. Health Policy 108, 100-104.

35. Nollen NL, Befort CA, Snow P et al. (2007) The school food environment and adolescent obesity: qualitative insights from high school principals and food service personnel. Int J Behav Nutr Phys Act 4, 18.

36. Pettigrew S, Donovan RJ, Jalleh G et al. (2013) Predictors of positive outcomes of a school food provision policy in Australia. Health Promot Int 29, 317-327.

37. Kubik MY, Lytle LA \& Farbakhsh K (2011) School and district wellness councils and availability of low-nutrient, energydense vending fare in Minnesota middle and high schools. J Am Diet Assoc 111, 150-155.

38. Mincher JL, Symons CW \& Thompson A (2012) A comparison of food policy and practice reporting between credentialed and noncredentialed Ohio school foodservice directors. J Acad Nutr Diet 112, 2035-2041.

39. Downs SM, Farmer A, Quintanilha M et al. (2012) From paper to practice: barriers to adopting nutrition guidelines in schools. J Nutr Educ Behav 44, 114-122.

40. Checkland K, Harrison S \& Marshall M (2007) Is the metaphor of 'barriers to change' useful in understanding implementation? Evidence from general medical practice. J Health Serv Res Policy 12, 95-100.

41. Vareilles G, Pommier J, Kane S et al. (2015) Understanding the motivation and performance of community health volunteers involved in the delivery of health programmes in Kampala, Uganda: a realist evaluation protocol. BMJ Open 5, e006752.

42. The PLOS Medicine Editors (2013) Addressing the wicked problem of obesity through planning and policies. PLOS Med 10, 1-3.

43. Wong G, Westhorp G, Manzano A et al. (2016) RAMSES II reporting standards for realist evaluations. BMC Med 14, $1-18$.

44. Levay AV, Chapman GE, Seed B et al. (2019) District-level implementation of British Columbia's school food and beverage sales policy: a realist evaluation exploring intervention mechanisms in urban and rural contexts. Can JPublic Health 110, 21-30.

45. Levay AV (2018) A realist implementation evaluation of British Columbia's school food and beverage sales policy. Doctoral Dissertation, University of British Columbia.

46. Jagosh J, Bush PL, Salsberg J et al. (2015) A realist evaluation of community-based participatory research: partnership synergy, trust building and related ripple effects. BMC Public Health 15, 1-11.

47. ATLAS.ti (2015) ATLAS.ti: Qualitative Analyse und Datenauswertung - ATLAS.ti Software version 7.5.9. 
48. Levay AV, Chapman GE, Seed B et al. (2018) 'It's just the right thing to do': conceptualizing a theory of change for a school food and beverage sales environment intervention and implications for implementation evaluation. Eval Program Plann 70, 73-82.

49. Jackson SF \& Kolla G (2012) A new realistic evaluation analysis method: linked coding of context, mechanism, and outcome relationships. Am J Eval 33, 339-349.

50. Friedman DA (2014) Public health regulation and the limits of paternalism. Conn Law Rev 46, 1687-1770.

51. Kubik MY, Lytle LA \& Story M (2005) Soft drinks, candy, and fast food: what parents and teachers think about the middle school food environment. I Am Diet Assoc 105 233-239.

52. Spitters H, Schwartz M \& Veugelers PJ (2009) Parent and student support for school policies that promote healthy eating and active living. Phys Health Educ 75, 30-34.

53. Devi A, Surender R \& Rayner M (2010) Improving the food environment in UK schools: policy opportunities and challenges. J Public Health Policy 31, 212-226.

54. Morgan K (2006) School food and the public domain: the politics of the public plate. Polit $Q \mathbf{7 7}, 379-387$.

55. Levay AL, Chapman G \& Seed B (2018) Implementer resistance to school food policy: unpacking the paradox. $\mathrm{Br}$ Food J 120, 1859-1875.

56. Hendrickson M \& James HS (2005) The ethics of constrained choice: how the industrialization of agriculture impacts farming and farmer behavior. J Agric Environ Ethics 18, 269-291.

57. Hendrickson M \& James HS (2016) Power, fairness and constrained choice in agricultural markets: a synthesizing framework. J Agric Environ Ethics 29, 945-967.

58. Stuart D \& Schewe RL (2016) constrained choice and climate change mitigation in US agriculture: structural barriers to a climate change ethic. I Agric Environ Ethics 29, 369-385.
59. Baumeister RF, Masicampo EJ \& DeWall CN (2009) Prosocial benefits of feeling free: disbelief in free will increases aggression and reduces helpfulness. Pers Soc Psychol Bull 35, 260-268.

60. Iyengar SS \& Lepper MR (1999) Rethinking the value of choice: a cultural perspective on intrinsic motivation. $J$ Pers Soc Psychol 76, 349-366.

61. Scott C, Hawkins B \& Knai C (2017) Food and beverage product reformulation as a corporate political strategy. Soc Sci Med 172, 37-45.

62. Bennet PR \& Bergstrom H (2015) Displaying parental responsibility for childhood obesity: aspects of care and family relationships. Fam Relatsh Soc 4, 19-33.

63. Kaufman L \& Karpati A (2007) Understanding the sociocultural roots of childhood obesity: food practices among Latino families in Bushwick, Brooklyn. Soc Sci Med 64 , $2177-2188$.

64. Maher J, Fraser S \& Wright J (2010) Framing the mother: childhood obesity, maternal responsibility and care. J Gend Stud 19, 233-247.

65. Mcisaac J-LD, Shearer CL, Veugelers PJ et al. (2015) Moving forward with school nutrition policies: a case study of policy adherence in Nova Scotia. Can J Diet Pract Res 76, 172-177.

66. Quintanilha M, Downs S, Lieffers J et al. (2013) Factors and barriers associated with early adoption of nutrition guidelines in Alberta, Canada. J Nutr Educ Behav 45, 510-517.

67. Jameton A (1984) Nursing Practice: The Ethical Issues. Englewood Cliffs, NJ: Prentice-Hall.

68. Lins Fumis RR, Junqueira GA, Fatima Nascimento A et al. (2017) Moral distress and its contribution to the development of burnout syndrome among critical care providers. Ann Intensive Care 7, 1-8.

69. Leiter MP, Frank E \& Matheson TJ (2009) Demand, values, and burnout: relevance for physicians. Can Fam Physician 55, 1224-1225. 